\title{
Micro Finance for Poverty Alleviation: A Commercialized View
}

\author{
Nikhil Chandra Shil \\ East West University \\ 43, Mohakhali C/A, Dhaka - 1212, Bangladesh \\ Tel: 88-02-9887989(Hunting) ext 253, 01819289589 (M) \\ E-mail: nikhilacc@yahoo.com Web: www.ewubd.edu
}

\begin{abstract}
The world is getting more matured in terms of level of sophistication. At the same time it becomes a threat due to the difficulty of having areas where further sophistication is possible. But, now, the most sensitive problem for all is the severe poverty. It is the darkest chapter of the world where more and more people are enlisting their names. If this process continued for unlimited time, once it will be suicidal for all of us irrespective of poor or rich. This paper put focus on the poor society, which concludes that if the poor are funded and focused, they can build their own fate. The poor need funds and suggestions to get rid of the curse of poverty. Grameen Model is outlined here with some replicated ideas so that it can be used in a more sophisticated and commercial way. Such commercialization will help to extend the scope of credit program from individuals to small businesses for which sometimes it may be difficult to get loan from regulated financial institutions. An earnest effort has been made to make the micro-credit programs and methodologies comprehendible with the process of diffusion and usability from a commercial perspective. Such perspective is important to give micro finance program an institutional modality that will ultimately ensure long-term existence.
\end{abstract}

Keywords: Micro Finance, Poverty Alleviation, Commercialization, Grameen Model, Bangladesh.

\section{Introduction}

"Poverty" and "Poverty Alleviation" are frequently heard buzzwords today. Poverty is a multidimensional phenomenon and depends on the context and perspective that one is looking at. A working definition from Professor Muhammad Yunus, the Noble Peace Price winner in 2006, is: Poverty is that characteristic of being in a state of joblessness, illiteracy, landlessness, homelessness, lack of adequate capital, facilities and food to earn a decent living and also powerlessness. Poverty alleviation is, therefore, the act of reducing the scourges of the above conditions of an individual or community. According to a statistics, about 1.6 billion people on the globe are in absolute poverty and the number is rising (Jammeh, 2002). All these poor people need help. And, poverty alleviation projects got priority at the time of fund allocation through budget in most of the developing countries.

Helping the poor is not so simple and easy as it is embedded within our socio-economic culture in an inseparable manner. There are various ways of helping the poor and one key way is the use of micro finance services. Micro finance has already got a lot of definitions and structures. Joanna Ledgerwood, a professional at the World Bank, defined micro finance as the provision of financial services to low-income clients (the poor), including the self-employed ones. She says that the financial services generally include savings and credit provisions (Jammeh, 2002). Last few decades are remarkable as the world witnessed a rapid growth of micro finance institutions (MFIs) to make the services reachable to the poor. MFIs use various lending models throughout the world. Some of the major lending models are: the Grameen model and its Solidarity Group version, Cooperatives and credit union model, visaca/village and Community Banking Model, and Rotating Savings and Credit Association (ROSACA) or Osusu model, Self Help Group (SHG) - Bank Linkage Model etc.

Fund is the constraint resources for most of the businesses. Thus, the success of business depends on the availability of fund. Micro finance programs ensure availability of fund without collateral. The methodology, introduced by Grameen Bank as Grameen Model, has ushered a new paradigm in lending arena. The success of the model attracted practitioners across the globe to replicate the same and the world has witnessed a large number of successful stories of how people are coming out of poverty.

The World Microcredit Summit Campaign, in its website for Countdown 2005, has outlined nine best practices for microfinance (Jammeh, 2002), which are as follows:

(a) Ensuring loan repayment.

(b) Moving towards institutional sustainability. 
(c) Targeting the poorest and covering costs.

(d) Sustainability in industrialized countries.

(e) Empowering women.

(f) Establishment and use of poverty measurement tools.

(g) Measuring impact on the lives of clients.

(h) Mobilizing savings and ensuring their safe use.

(i) Recruiting, training and retaining excellent staff.

The combination of these best practices in the appropriate proportions is useful in poverty alleviation and other development plans. However, since microfinance deals with both business and human relationship, which involve a lot of risk-taking, the risks taken need to be managed properly.

In this paper, the Grameen Model has been outlined as a successful model of microfinance that is replicated in most of the countries over the globe. This represents its acceptance by global community. Grameen model is critically presented here with the preconditions, necessities and prospects of commercialization to ensure a sustainable economic development by alleviating poverty. The conventional micro credit model is refined conceptually in a substantial manner to give it all possible shape and to harvest maximum benefits out of it by the poor folk of the society. With the progress of commercialization, such micro finance facilities may also be opened for small businesses to ensure smooth economic development. Thus, the paper has policy interest also. Micro finance as presented here will work as a weapon against poverty for poor folk of the society and at the same time if it can be commercialized in true sense, small enterprises will be benefited by getting loans easily.

\section{Background}

Micro credit and Grameen Bank are inseparable concept for the discussion of the literature. Grameen Bank is the institutionalized version of micro credit model. And, Professor Muhammad Yunus, the developer of micro credit concept, and the Grameen Bank becomes the symbol of pride for Bangladesh with the declaration of Noble Peace Price in 2006. Micro credit, thus, gets global recognition. Due to such recognition, more care is warranted regarding the use, implication and effect of micro credit on the poverty level to keep its original essence intact. Monopolistic power, excessive interest rates and exploitation through under-valuation of collaterals have restricted the informal financial sector to provide credit to poor people for income generating and poverty alleviation purposes (Bhaduri, 1983; Rao, 1980; Bardhan, 1980; Ghosh, 1986, Ghate et. al., 1992). The limitations of the formal and informal financial sector in providing financial services, especially credit, encouraged the micro credit program to evolve. The micro credit program was initiated with the objective of providing poor people with credit without collateral. Professor Yunus called the process of substituting the provision of collateral with group harmony and other aspects of micro credit as 'freeing of credit from the bondage of collateral' (Yunus, 1997). The traditional Micro credit model was so simple where bank or non-banking financial institutions give credit directly to self-help group $(S H G)$ or through $N G O s$ as shown below (Figure 1).

\section{Insert Figure 1 Approximately Here}

The origin of the current microcredit model can be traced back to action research in the late 1970s, carried out by academics as well as practitioners in organizations that were created to deal with the relief and rehabilitation needs of post-independence Bangladesh. The 1980s witnessed a growing number of non-governmental organizations (NGOs) experimenting with different modalities of delivering credit to the poor. The predominant model become one of providing individual loans to a target group of poor households, rather than providing loans for group projects which suffered from a 'free-rider problem'. The various models converged around the beginning of the 1990s toward a fairly uniform "Grameen-model" of delivering micro credit (Zaman, 2004). A 'franchising approach' whereby new branches copied the procedures and norms that prevailed in existing branches fueled the Grameen-style growth. From the mid 1990s onward, it became clear that the standardized model of providing micro credit with fixed repayment schedules and with standard floors and ceiling on loan size were not sufficient to meet the needs of the extreme poor. In recent years, the standard Grameen-model has undergone greater refinement in order to cater to different niche markets as well as to different life-cycle circumstances. Figure 2 below shows the growing demand of micro credit facilities over a period of about 6 years (2003 - April, 2006)

Insert Figure 2 Approximately Here

The micro credit is only the one side of microfinance industry. The poorest households also have an effective demand for safe deposit facilities (Rutherford, 2000). While the amount of their deposits is small, this does not mean a lack of demand. With flexible deposit and loan products, SafeSave in Bangladesh has been able to reach some of the poorest 
households in Dhaka slums. Similarly, about 7\% of Mibanco clients in Peru belonged to the poorest category (ACCION International, 2003).

Questioning the clubbing of varied forms of credit lending such as moneylender's credit, pawn shops, agricultural credit, livestock credit, rural credit or cooperative credit etc under the broad label of 'micro-credit', Yunus proposed a definition of 'Grameen credit' which embodies the principles of the Grameen Bank (Murthy, 2005). The objectives of the Grameen Bank are: to extend banking facilities to poor men and women; eliminate the exploitation of the poor by moneylenders; create opportunities for self-employment for the vast multitude of unemployed in rural Bangladesh; bring the disadvantaged, mostly women from the poorest households, within the fold of an organizational format which they could understand and manage by themselves; and reverse the age-old vicious circle of 'low income, low saving and low investment' into a virtuous circle of 'low income, injection of credit, investment, more income, more savings, more investment, more income' (Figure 3).

Insert Figure 3 Approximately Here

It is remarkable that the micro finance industry in Bangladesh has been able to provide access to credit to around 13 million poor households. There are around twelve hundred micro finance institutions currently in Bangladesh, although the industry is heavily concentrated in a handful of large organizations-Grameen Bank, BRAC, ASA, and Proshika. These four cover around eleven and a half million or 90 percent of all clients as shown in Table 1.

\section{Insert Table 1 Approximately Here}

Looking at Bangladesh's experience in perspective, one can argue that the current, remarkable access level is attributable to some specific factors:

First is visionary leadership within the pioneering microfinance organizations. The founders and leaders of Grameen Bank and $B R A C$, in particular, created decentralized structures with appropriate incentives that encouraged high staff performance, which in turn underpinned rational expansion based on existing capacity and client demand.

Second, the government of Bangladesh created a supportive macro-economic environment and implemented a "hands-off" regulatory policy.

Third, donors played a constructive role by providing resources at the appropriate time. This included funding the initial expansion phase of several micro finance institutions and then building the institutional capacity and systems needed to ensure sustainability.

Fourth, high population density and relative ethnic, social, and cultural homogeneity made "franchising" the micro-credit model less difficult, and significantly propelled its expansion.

Fifth, the public-private micro-credit "wholesaler", PKSF, was able to take advantage of already-established retail capacity to scale up the micro credit industry, as well as demand professional standards and a focus on sustainability.

\section{Methodology}

The basic foundation of the study is based on the secondary sources of information like research papers, conference papers, working papers, speeches, web documents, books etc. Primary sources of information are limited to personal observation and face-to-face interviews. Micro credit models, its replication and commercialization issues come from the secondary sources. And modification or extension to the current models is the result of critical observation and interviews with the facilitators, both the lenders and borrowers.

\section{Grameen Model: A Poverty Alleviation Concept}

The Grameen Bank originated in rural Bangladesh in 1976. Initially, the Bank was formed to test the hypothesis that if financial resources were made available to the poor at reasonable rates of interest, they would be able to generate productive self-employment without external assistance. In line with this hypothesis, the target groups of the Bank are the poorest of the poor, who are almost exclusively women (McDonnell, 1999). Experience obtained by the Grameen Bank suggests that potential borrowers need to complete several steps in order to ensure loan repayment. Firstly, the members have to select five persons of their own to form a group. Loans are more likely to be repaid if groups include only individuals of the same gender, from the same village and from similar economic backgrounds (Khandker et al., 1995). Before a loan is granted, groups participate in a weeklong training program where they are taught the rules and regulations of the Bank. If the Bank is satisfied with the group's response to this training then loans are sanctioned. Each member identifies the purpose of his or her loan with guidance from other members of the group. Loans issued to new members are small, approximately BDT 2,000 to 5,000 with an upper limit of BDT 10,000. All loans are repaid in weekly installments over a period of a year. Interest rates are currently fixed at 20 percent per annum (Hossain, 1993).

To overcome problems of loan defaults, the Grameen Bank has developed a system of mutual accountability based on a peer group lending structure. Under this structure the group as a whole becomes ineligible to receive any additional loans if any member of the group defaults. This ensures that peer pressure is exerted on members to maintain regular 
payments. A group may decide to fine or expel a member who fails to attend group meetings or who willfully defaults on payments of installments. Conversely, groups may encourage and support a member who cannot repay in times of genuine difficulty. A member may leave the group when loan is repaid. If a member leaves before repaying loan, the responsibility for repayment falls on the group as a whole. In this way the mutual accountability fostered by the Bank works as a form of social capital, as opposed to the financial capital, which is the basis for mainstream commercial banking (Hossain, 1988).

The process of forming groups by allowing members to self-select has been found to reduce the credit risks associated with lending. Each member of a group is awarded loans depending on the outcome of other members' loans; individuals have an incentive to join a group where all members have an equal, if not lower, credit risk than themselves (Varian, 1990). Simply when one individual has a higher credit risk than all other group members, then that individual is being subsidized by the rest of the group (Stiglitz, 1990). The Grameen Bank policy of lending to relatively homogenous groups comprising of members of the same sex and from similar economic backgrounds helps to explain why the Bank's repayment rates are far higher than loans programs in which groups are formed on the basis of administrative decisions (Huppi and Feder, 1990). Thus it appears that successful peer monitoring requires that borrower groups are comprised of relatively homogeneous membership.

Successful peer monitoring also requires a small borrower group. Small groups foster closer ties among members and can reduce the cost associated with accessing information. Practice has shown that group size has a marked impact on the repayment rate associated with loans, with groups of 100 members performing far worse than groups of 10 to 20 members. The Grameen Bank has settled on a group size of five through a process of trial and error. Initially the size of Grameen Bank groups was ten or more members. This proved unsatisfactory however, because as groups become larger the diversity among the economic conditions of members increased and the decision-making process became lengthy. Finally five-member groups proved the most practical size (Huppi and Feder, 1990). Another reason for maintaining a small group size is that as group size increases, the incentives of individual members to monitor the action of their peer falls. This reduced incentive occurs because with increasing membership the costs to each individual from a defaulting member falls and therefore the incentive to monitor behavior decreases. Finally, it is argued that there is a free-rider problem associated with large groups in that each member would prefer that others monitor and incur the ill will resulting from reporting offenders who have misused the funds lent to them (Stiglitz, 1990).

\section{Insert Figure 4 Approximately Here}

The social relationship or social capital that exists between members also has a direct impact on the repayment rate of a group. A dominant feature of many communities in developed countries is the degree of interdependency that exists between individuals. Within this context village organizations often serve to provide welfare services and infrastructure. Participation in village life often requires a restraint on self-interested behavior and a variety of enforcement mechanisms, in the form of social sanctions, are invoked to ensure this. Working from this understanding, it has been argued that if an individual does not repay their loan this will cause a loss to other members of the group invoking social sanctions against the defaulting member (Besley and Coate, 1995; Cable and Shane, 1997). The types of penalties that may be imposed on a defaulting member of a group include the loss of material goods and reputation. Within the Grameen Bank, contributing members report the behavior of a defaulting member at a central meeting, thereby augmenting the admonishment felt by the defaulting member. Also other members of the group will reduce their cooperation with the defaulting member in the future. This penalty can be particularly devastating if there is some form of exchange or mutual support that occurs between group members independent of the loan scheme. For example, group members may rely on each other's help in productive activities or may help each other in times of trouble. Finally, if social penalties are sufficiently severe, group lending will yield higher repayment rates than individual lending (Beasley and Coate, 1995).

Thus it appears that social capital, in the form of sanctions available to community members to discipline poor repayment behavior, is a key element in the operation of group lending schemes. This may explain why group-lending schemes, such as the Grameen Bank, have been so successful in developing countries where interdependence within communities is typically high (Besley and Coate, 1995). In contrast, an absence of interdependence in most communities in developed countries may help to explain why group-lending schemes in these countries have been less successful.

Indications of the success of the Grameen Bank's micro credit model in Bangladesh are the repayment rate of its loans and in the benefits accompanying its membership. Between 1987 and 1992 the repayment rates of the Grameen Bank's individual loans were consistently in excess of 95 percent. These repayment rates are higher than those recorded by most mainstream financial institutions. In terms of the benefits that accrue to members, studies indicate that membership of the Grameen Bank empowers women (who make up approximately 95 per cent of all members) (Rahman, 1986; Goetz and Sen Gupta, 1994; Hashemi et al., 1996), increases the income and employment opportunities of members (Hossain, 1985, 1988; Alam, 1988; Khandker et al., 1995) and improves their housing (Rahman and Hasnat, 
1993; Wahid, 1994) and nutrition (Wahid, 1994). Interests paid by the borrowers are not subsidized. Charging a relatively high interest rate that covers the full cost of the program and which the poor are apparently willing to pay, appears to be a win-win proposition (Morduch, 1997). This strategy is consistent with the lessons learnt from the experience of earlier cooperative and other government aided credit programs for the poor, whose failure has been blamed on the subsidized interest rate policy (Adams et al., 1984).

\section{Grameen Model Replicated}

The financial viability of the Grameen Bank and its ability to promote welfare gains for the poor has led to attempts to replicate the model in developing countries in Asia, Latin America and Africa, and in developed countries such as the United States, Canada and Australia. The Grameen Bank Replication Program of Grameen Foundation USA was established in 1999 to support institutions and social entrepreneurs throughout the world who seek to replicate the Grameen Bank approach, or scale up existing programs to provide financial services to the poor. Through 52 partners in 22 countries (including the US), the Grameen Foundation USA currently affects close to 1.2 million of the world's poorest families (Grameen Foundation USA, 2004). Jain and Moore (2003) note several reasons that the Grameen model has become the most important in terms of replication. Some of these are to do with the Grameen Bank itself, its relatively early development, and its leadership, which has been especially active and effective in publicizing the virtues of the Grameen model and in doing so in terms that appeal to donors. MEDA was the first organization to promote micro-finance through savings and loan cooperatives in Bolivia. The rapid success that it had with San Luis and other partners created a demonstration effect. According to staff interviewed, following MEDA's lead, other cooperatives began to develop micro-finance programs (Hamilton, 2000).

Muhammad Yunus, the founder of the Grameen Bank, as well as other founder of Grameen Bank replications in Asia, advocate an approach in which that the Bank model can be used as a pilot project in another country. Under this approach the Grameen Bank is first introduced as a small-scale experiment in a new country. The experiment is closely monitored and the institution is modified to suit its new environment. Importantly, the learning process approach recognizes the inherently experimental nature of the transfer process and acknowledges that success is not guaranteed (Hulme, 1990).

Features relevant to the process of replication include the ability to reduce costs incurred by a lending agency by maintaining high repayment rates and lowering transaction costs incurred by borrowers (Hulme, 1990; Todd, 1996). The experience in Malaysia, Sri Lanka and Peru has pointed out that the high repayment rate of the Grameen Bank is closely associated with its peer group lending structure. In these countries the peer lending structure enables agencies to keep costs low by allowing field officers to handle relatively high account loads, up to 300 per officer (Hulme, 1990; Todd, 1996).

As mentioned earlier, the ideas and methods of the Grameen Bank have not simply diffused across Bangladesh; they have spread across the world. The global image of microfinance is shaped by Grameen Bank and there are at least 52 direct Grameen replicates operating worldwide, including in the US. Formally, there are two direct mechanisms through which such policy transfer operates. First, the Grameen Bank runs scores of international seminars each year that train people from other countries to learn how to replicate Grameen Bank. It provides field visits, manuals, puts participants into a replicators network and can even provide start up grants through linking to the Grameen Bank Replication Program. The Grameen Trusts newsletter (Grameen Dialogue) lists 131 partner organizations in 35 countries (April 2005) with a client base of over 1.8 million in October 2004. The second mechanism is the Microcredit Summit. Different style of micro finance is depicted below (Figure 5) that is also the outcome of replication.

\section{Insert Figure 5 Approximately Here}

Micro finance program may be run for group or individuals. Individual lending programs run by commercial banks in a commercialized way. But, group-lending programs are run by NGOs or MFIs or sometimes some designated banks working in these area. The Group Model's basic philosophy lies in the fact that shortcomings and weaknesses at the individual level are overcome by the collective responsibility and security afforded by the formation of a group of such individuals. Such group may be solidarity or community-based organizations. Grameen Model used by Grameen Bank is the best example of solidarity group. Village banking was pioneered by the Foundation for International Community Assistance (FINCA International). Founded in 1984 by American economist and development practitioner John Hatch, FINCA began in Bolivia, spread throughout South America and had expanded into Africa by 1992. It is a good example of CMLF. Rotating Savings and Credit Associations (ROSCAs) are essentially a group of individuals who come together and make regular cyclical contributions to a common fund, which is then given as a lump sum to one member in each cycle.

\section{Criticism of Micro Credit and a Targeted Snapshot}

Ironically, the so-called exploitative moneylender has been replaced with an army of moneylenders. Though the motive was to drive the exploitative moneylender away, in effect exploitation has been legitimized through the neo-institutional 
mechanism of micro-credit. With interest rates exceeding the repayment capacity of the poor, a debt-trap has been laid. Micro credit has been designed to create an illusion, much like electoral promises. At the cost of the poor in Bangladesh, Grameen has grown to sky-scraping heights (Sharma, 2005). Micro credit programs across the world have bagged a lot of criticisms like these. Some of the specific criticisms of micro credit programs are:

(1) They are wrongly offered as the Solutions or Panacea to eradicate poverty;

(2) It is a trap of indebting the poor;

(3) Poor are asked to look after themselves;

(4) Coercion and high rate of interests are common observations;

(5) It does not help the poorest of the poor;

(6) Men are left out but the credit reaches men through women and is misused and burden of repayment lies on women. The author personally come up with a situation where the husband pressurized the wife to get loan and then the husband went for a second marriage spending the loaned money divorcing the first wife.

(7) Ironically, in most of the schemes, women's own money is locked up, and they are forced to take a loan against their own savings at a higher interest. NGOs have become collecting agents for banks which are trying to increase their penetration of credit. (Murthy, 2005)

(8) NGOs, banks and corporations have benefited from micro-credit at the cost of the poor (Sharma, 2005)

(9) It is being used to promote products of MNCs.

(10) Women empowerment was a basic target of grameen model of micro credit. But the reality is different. As per one study, only $0.2 \%$ of Global commercial lending reaches to the poor women. A study of 38 branches of major banks in India found that only $11 \%$ of the borrowers are women (UNDP, 1995). So the present schemes of NABARD, SIDBI and Rashtriya Mahila Kosh are welcomed, as they are able to cater to the poor through SHGs.

Now, in the light of the criticisms as mentioned above, the author believes that the conventional micro credit models are targeted to ensure the sustainability of the credit giving institutions (MFIs). It operates in a way of so called good sounding theories where a very short period is targeted. But, poverty is not a short-term phenomenon. The current models undoubtedly give independence from hunger, ensure works or jobs but at the cost of long-term sustainability that can never alleviate poverty from the economic structure. The current models need a targeted snapshot where lenders will have a vision in mind regarding what they want the photographs look like after, say, 20 years. Let me explain the way. Everything is ok with the current model except a focus that the poor people need. They need funds, they need jobs/works, they need earnings, and they also need suggestions to spend their earnings. The micro credit model can be reproduced with this new insight as presented in figure 6 .

Insert Figure 6 Approximately Here

Conventional micro credit model have no indications regarding the uses of earnings. Such models like to look after the invested fund, not for the effective use of it but for timely recovery. And there are special provisions for the defaulters. Under the current models, the success is often sought for ensuring earnings to those who have no or less earnings earlier, for ensuring foods three times a day who might remain starved earlier. The models can be compared with the Chinese Proverb of: "Feeding Fish to someone who has no access to fish." But we should materialize the learning from the proverb: "Without giving fish to someone, let him learn the way of catching fish. Then you will ensure fish for him throughout the life."

The persons, who qualify the loan/credit, have such potentiality to earn. But, most often they lack the capacity to utilize the earnings. If the credit giving institutions help them in this respect, it will be helpful for them and for the society as well. Here, five possible areas have been identified as per the availability or sufficiency of earnings to add new insight with the model. If all of the areas are taken care off, poverty will be a history for a community.

(1) Loan repayment: This will be the first responsibility of the borrowers to repay the loan as per the terms. This is needed for the sustainability of the loan giving institution to have a long continuance so that more and more individuals can avail the facility.

(2) Family consumption: Earnings lead a man to have a decent living. For a poor man, a decent living means ensuring of food for the family members so that the family enjoys full independence from hunger. For such expenditure, the world economy will be benefited due to pressure in demand that leads to maximum production.

(3) Community development: A portion of earnings may be used for the development of the community, which will ensure a supportive environment for all of us. It is our commitment towards the society where we live in. 
(4) Capacity building: Poverty will never be alleviated if we cannot ensure our full independence from illiteracy and ignorance. We must not expect that profession will be inherited. To develop a strong generation, we need investment in capacity building. We should take oath: 'No child will work as infant; rather they will go to school.' Only then, they can build their own fortune. This is a must for ensuring long-term retirement of poverty.

(5) Savings: Savings is for the independence from micro credit itself. We expect that the circle of micro credit will stop today or tomorrow due to accumulation of savings that will once finance the project.

\section{Commercialization Approach}

Commercialization is characterized, according to Christen (2001), by profitability, competition, and regulation, but at the same time large differences in loan size are observed between regulated and unregulated institutions. In 2001 Christen inventoried 205 MFIs in Latin America, where seventy-seven MFIs (37.6\%) were regulated and accounted for $73.9 \%$ of a US\$ 877 million portfolio. In general, this phenomenon has been called the commercialization of microfinance. While unregulated MFIs recorded an average outstanding loan size of US\$ 322 in 1999, regulated institutions recorded US\$ 803, which is 2.5 times larger. Assessed in terms of relative wealth, the average outstanding loan size for unregulated MFIs represented $24 \%$ of GNP per capita in 1999, while for regulated MFIs this percentage was $49 \%$.

As already mentioned it is useful to highlight the three key principles of what constitutes a commercial approach to micro finance: profitability, competition, and regulation. First and foremost, commercialization of microfinance is reflected in strong financial performance. Second, once microfinance institutions are committed to managing business on a commercial basis, competition quickly becomes a hallmark of the environment in which they operate. The very profits created by pioneering $N G O s$ generate a demonstration effect, attracting others to follow suit and offer similar services. This, in turn, forces microfinance institutions to begin to make changes in product design, pricing, delivery mechanisms, or other basic features of classic businesses to preserve or increase their market share. Third, reaching sustainability is a precondition for obtaining a license, so it can be assumed that licensed, regulated microfinance institutions have already adopted a commercial approach. Regulated microfinance institutions are far more sustainable than unregulated microfinance institutions, although many of them started out as unregulated or specially licensed organizations clearly rooted in the non-profit sector.

\section{Progress of Microfinance towards Commercialization}

The strong financial performance of larger MFIs in Latin America is linked with a trend toward commercialization of microfinance in the region. In 1992 Banco Sol became the first example of an $N G O$ transformation to a commercial bank and thus became the first regulated microfinance bank. Banco Sol surpassed other Bolivian banks in profitability and became the first $M F I$ to access international capital markets. Following this successful example, at least 39 other important NGOs worldwide transformed into commercial banks over the period 1992- 2003 (Fernando, 2003). But, the transformation is not so simple. It is a sequential process as figured out (Figure 7) below:

Insert Figure 7 Approximately Here

Commercialization of microfinance is a relatively new consideration in Bangladesh. The term commercialization carries with it a negative connotation among many domestic microfinance stakeholders who equate commercialization with exploitation of the poor. Microfinance professionals worldwide, however, are increasingly using the term to include "the application of market-based principles to microfinance," with the realization that only through achievements in sustainability can MFIs achieve levels of outreach commensurate with demand. There is a growing realization that commercialization allows MFIs greater opportunity to fulfill their social objectives of providing the poor with increased access to an array of demand driven micro finance products and services, including not only credit but also savings, insurance, payments, and money transfers. In Bangladesh, we have already witnessed that some banks are offering collateral free loan to SMEs. Thus, the process of commercialization is on the way. Level of outreach will be increased for the small businessmen once this become a competition in formal and regulated financial sector.

Commercialization of microfinance industry involves several factors, including the degree to which the policy environment and legal and regulatory framework are conducive to the proliferation of commercialized MFIs, sufficient institutional capability, availability and access of market-based sources of funds to MFIs, etc.

\section{Roles needed for Commercialization}

The array of factors inhibiting the commercialization of microfinance implies specific roles for major stakeholders such as the government, funding agencies, MFIs themselves, and microfinance support institutions such as PKSF and CDE. General responsibilities and specific approaches to move commercialization forward are highlighted below for these stakeholders.

\subsection{Roles of the government}

Action by the Government of Bangladesh $(\mathrm{GoB})$ is pivotal to the successful advancement of microfinance commercialization. Government can enable favorable policy environment for its advancement. It can also withdraw 
maximum interventions so that more clients can avail the facilities and all financial institutions can engage themselves in micro finance program. In this case, government should also be careful to invest in physical infrastructure and provision of human services, particularly in rural areas, have the potential to boost effective demand for microfinance. A legal structure for commercial MFIs are of greater importance so that both deposit mobilization and lending can be done in a balanced way. It is very much important for sustainability of microfinance enterprises drawing from recent positive international experiences in Africa and Latin America. Government can also play a crucial role for ensuring security of the transactions devising new legal framework for micro finance operations.

\section{Insert Table 2 Approximately Here}

\subsection{Roles of funding agencies}

The role of the government is not enough for achieving success. Funding agencies have to work with the government to reduce the problems. They can help the government to develop an effective policy, legal and regulatory environment. In addition, they can help the MFIs to be self equipped by giving suggestions, assistances, trainings and any other needs required from time to time. This will help the MFIs to develop new market, enterprises, products, ideas etc. They can also help to develop a linkage between MFIs and NGOs with Banks to avail commercial funds.

\subsection{Role of Microfinance Institutions}

MFIs, themselves, have to do a lot to be transformed. They have to make a balance between profitability and poverty alleviation. They have to fulfill both commercial and social objectives though conflicting most often. To do this, they have to be cost effective. ASA's ability to reduce costs and keep interest rates low is the proof that very high efficiencies can be attained, even when serving poor people. They have to improve institutional capacity also to ensure sustainability.

\subsection{Role of Micro Finance Industry Support Organizations}

PKSF and CDF are major microfinance-support organizations that can play a leadership role in moving microfinance commercialization forward.

\subsubsection{PKSF}

$P K S F$ can accelerate the pace of microfinance commercialization if they want, by eliminating its maximum on-lending interest rate criterion with support from the government. $P K S F$ is an important member of the 11-member steering committee on regulation and is also the convener of the 8-member technical committee. It can influence the government through selected policymakers to design supportive regulation and supervision standards for the proposed new tier of specialized financial institutions engaging in microfinance.

\subsubsection{Credit and Development Forum (CDF)}

$C D F$ can work for introducing a standard accounting system for its members and other MFIs. Its capacity building programs are consistent with commercialization and should be expanded because they stress operational and financial self-sustainability, product pricing/costing, cost efficiency, productivity and linking its partners with commercial sources of funds.

\subsubsection{Credit Information Bureau (CIB)}

$C I B$ is very much important to commercialize the microfinance industry from where anyone can access the creditworthiness of any customer before sanctioning loans. All microfinance $N G O s$ can come to a consensus to form such a $C I B$ with their information and the information database will increase with the passage of time. For the first time, the government or funding agencies could fund a pilot system for sharing information on blacklisted clients before forming a full-fledged $C I B$.

\section{Challenges and Implications of Microfinance Commercialization}

Several challenges to microfinance commercialization exist at institutional (micro) and operational environment (macro) levels with both positive and negative implications. Proper care is the precondition to reap the maximum benefit out of it.

Most of the microfinance challenges come from the strong acceptability of $N G O s$ by the target group. People have wrong perception that $N G O s$ are working for poverty alleviation but other financial institutions are working to make profit that must not go with poverty alleviation. Again, if our NGOs want to transform, in most of the cases they cannot, as they haven't the required institutional capability in terms of skilled manpower, infrastructure, cost structure etc. Our MFIs have no clear vision about what to achieve. This is due to the fact that over the decades they are running their poverty alleviation program and it becomes our national slogan but the result is not satisfactory. Till, an amazing number of people cannot avail the fund or if availed, cannot use it to get out of the net of poverty. Even micro credit program run by government has showed a poor performance. Another important challenge is lack of collateral, as poor people have no assets to back their loan and so a higher level of risk on non-repayment is very much prevalent here. For 
reducing this risk to some extent a credit information bureau $(C I B)$ is required to be formed with all necessary institutional, regulatory and legal formalities. The legal and regulatory environment must be supportive and conducive with a clear vision of the respective authorities. A true commercialization should have the motive to reduce the demand of soft or subsidized or donated loans that will ultimately reduce our donor dependency and leads us to financial and economic sustainability. At the end of 2000 , such funds accounted for about $41 \%$ of the loanable funds for the microfinance industry. It is obviously a bad signal for the sound development of financial and capital market.

Commercialization has a lot of positive and negative implications. Most of its negative implications generates from human psychology, controversial explanation and flaws of application that can easily be solved if the authority has sufficient commitment. Critics of commercialization believe that it leads to 'mission drift' by giving less focus on the poorest of the poor. Thus many poor households would remain unserved who are presently under the net of micro credit. Focus may also be lessening from women folk who have a great contribution towards family income. Commercialization may also increase the loan sizes by reducing the number of clients to ensure more control and reduce transaction and recovery costs. The rate of interest may rise due to the fact that the invested funds will have costs that will be recovered by charging the loan receiver only. These are the negative perceptions of potential users against commercialization though most of the problems can easily be solved by a proper system.

\section{Commercialization Model}

Commercialization has no generalized model. But from the available literature, a model can be proposed that is required to be adjusted with the country specific situations. For commercialization, any country must have favorable legal environment and then institutional capability comes. Last of all, we need to establish operational efficiency from commercial point of view. The total process is depicted in figure 8 .

A supportive external environment where such NGOs/MFIs work is the foremost requirement. Such support should be ensured in policy level. Say, in Bangladesh, if the Bangladesh Bank doesn't permit MFIs to operate in a commercialized way, commercialization becomes impossible. Once external environment becomes conducive, internal maturity comes into the limelight. Depending on the donated funds and suggestion commercialization cannot work. To apply commercialization, we need commercial funds, strategic capacity to ensure commercial management of fund and sustainability. And finally, operational efficiency is required to be ensured through the application of commercial principles in all possible respects. Here, the author strongly believes that if such micro finance program is run under commercial principles, not only the poor folk of the society but also the business world (small scale) will be benefited and the interest rate charged by the NGOs/MFIs will be dropped to a competitive level. It is really unexpected to have some negative comments on commercialization process on the ground of exploitation by charging higher rate of interest where NGOs/MFIs are charging the highest in the name of poverty alleviation.

Insert Figure 8 Approximately Here

\section{Prospects of Microfinance}

Both developed and developing countries still have a good market for the development and advancement of microfinance industry. Because there is a huge market gap that is required to be filled up to grasp the potential benefits from it. The market is growing, but the pace is very slow. The main reason is lack of commercialization. Here, most of the $N G O s$ provide donated funds at a subsidized rate. Transformation rate (from $N G O$ to $M F I$ to Commercial Bank) is very low. First thing that we need according to our proposed model is conducive regulatory environment to support the microfinance operation. Commercial Banks should be kept free to engage themselves in such operations that are not authorized in many countries. So, Central Bank may form a task force to conduct a feasibility study to evaluate whether full-fledged commercial banks can be given the permission to go for microfinance operation. Grameen Bank, BRAC Bank, Islami Bank Bangladesh Limited and some other financial institutions are enjoying the facilities and they are making a good fortune, if we take Bangladesh as a sample. If all banking and non-banking financial institutions avail the option, the breadth and depth of outreach can be maximized. The need for microfinance is higher in rural areas than in urban areas irrespective of the status of the country. Most of our unemployed and unproductive men and women live in rural areas who need works and funds. Sometimes they do not get work due to shortage of fund. Again, there are ample opportunities in rural areas to operate successful venture at minimal fund involvement in various agro-based projects. Indigenous people may also be a target group of microfinance industry who needs training and funds to expose them off. Thus commercialization of microfinance may work as an effective tonic here to bring our poor people out of the vicious circle of poverty. From NGOs, we cannot expect the maximum result so long as they will run by donated fund or soft and grant loans. If commercial banks come up with their expertise and commercial funds, the situation may be better. They can use their long trained staff, fund management policies, scattered branches to ensure outreach and last, but not the least, commercial funds with a commercial motive that leads not only to alleviate poverty but also to develop wealth-base of the destitute group. "Latin America is the most commercially advanced microfinance market in the world," says Roy Jacobowitz, vice president for resource development at ACCION, one of the world's largest microfinance institutions. Microfinance in Latin America has been characterized over the years by a clearly profit 
driven and competitive landscape that differs widely from the peer-group style lending championed by Grameen Bank of Bangladesh and other Asian and African models. It's a model that has had success in alleviating poverty in the region, helping to develop Third World economies and, more recently, creating a new asset class for private investors interested in a social return as well as a financial return. Thus, the prospect of microfinance is enormous. We can make it what Latin American Countries have already made. What we need is the clear vision and commitment.

\section{Conclusion}

Micro credit programs have a strongly positive relationship with poverty alleviation; this is the proven fact. But, the only requirement is that the loan giving authorities really mean it. It is not a simple task to help the poor, as they are poor in every respect. The geographical location of the poorest and the broader environment in which they operate also make it more difficult to serve them. For example, while the poorest can be found in urban areas, most of the poorest in Asia are concentrated in rural areas where basic physical infrastructure is highly inadequate (Haan and Michael, 1998). The bulk of the poorest in India are in such states as Bihar (including Jharkhand), Uttar Pradesh (including Uttaranchal) and Madhya Pradesh (including Chhatisgarh) (Mehta and Amita, 2003). These states have seen relatively very little institutional micro finance.

The poor are scattered throughout the remote geographical area where the outreach is so difficult and due to the rapidly increasing number of borrowers, a matured institutional set up is required. So, micro finance is required to be commercialized. Application of commercial principles in micro finance becomes a time demanding issue now a day with the increase in failure rate also. Micro-businesses (defined as those employing less than five people) have a high failure rate and are considered high-risk investments (Dahn, 1992). Micro-business borrowers seek to borrow sums that, because of their small, often non-standard, character, incur disproportionately high transaction costs (Dahn, 1992). Micro finance facility may suit them in such a situation.

Finally, if the group (target market, loan receivers) is identified rightly, if commercial principles can be applied equitably and if the poor are rightly and timely focused, micro finance may work as a strong and timely intervention against poverty that no laboratory can test and prove. It may work as a cause of smile for a vast majority poor people who suffer from acute poverty level in terms of hunger, illiteracy, ignorance, slavery, insecurity and such other in humanitarian condition. And if commercialized properly, small business entrepreneurs may find the program worthy for them also.

\section{References}

ACCION International. (2003). Poverty Outreach Findings: Mibanco, Peru. Insight No. 5. Boston: ACCION International.

Adams, D. W., Graham, D. H. \& Von Pischke, J. D. (1984). Undermining rural development with Cheap Credit. Boulder, Colorado: West view Press.

Alam, J. (1988). Rural poor in Bangladesh. A UNDP Report, UNDP, Dhaka.

Besley, T. and Coate, S. (1995). Group lending, repayment incentives and social collateral. Journal of Development Economics, 46 (1), 1-18.

Bardhan, P. K. (1980). Interlocking Factor Markets and Agrarian Development: A Review of Issues. Oxford Economic Papers, 35.

Bhaduri, A. (1983). The Economic Structure of Backward Agriculture. India: Macmillan India Limited.

Cable, D. M. \& Shane, S. (1997). A prisoner's dilemma approach to entrepreneur-venture capitalist relationships. Academy of Management Review, 22 (1), 142-76.

Christen, R. P. (2001). Commercialization and Mission Drift: The Transformation of Microfinance in Latin America. CGAP Occasional Paper no. 5: Washington DC.

Dahn, S. (1992). The missing link: a directory of financing initiatives for small business generated community economic development. Churchill Fellowship Report, Melbourne.

Daley-Harris, S. (2005). State of the Microcredit Summit Campaign Report 2005. Available at http://www. microcreditsummit.org/pubs/reports/socr/2005/SOCR05.pdf.

Fernando, N. (2003). Transformation of NGOs into Regulated Financial Institutions: expectations fulfilled? paper presented at ADBI Annual Conference, Microfinance in Asia: poverty impact and outreach to the poor, December, Tokyo.

Ghate, P., Gupta, A. D., Lamberte, M., Poapongsakorn, N., Prabowo, D., Rahman, A. \& Srinivasan,T. N. (1992). Informal Finance: Some Findings from Asia. Manila: For Asian Development Bank, Oxford University Press.

Ghosh, D. (1986). Monetary Dualism in Developing Countries. Ecomomies ET Societes. 
Goetz, A. M. \& Sen Gupta, R. (1994). Who Takes Care of the Credit? Gender, Power and Control Over Loan Use in Rural Credit Programs in Bangladesh. Institute of Development Studies, London.

Grameen Foundation USA. (2004). Annual Report 2004. Washington DC: Grameen Foundation USA. http://www.gfusa.org/docs/about_us/GFUSA-AnnualReport2004.pdf

Haan, Arjan de \& Michael, L. (1998). Poverty in Emerging Asia: Progress, Setbacks, and Log-jams. Asian Development Review, 16(2), 135-176.

Hamilton, E. (2000). MEDA international long-range study: Micro-finance projects in Bolivia. Appendix A, in Rempel et al, Promoting Development in Bolivia: An Assessment of MEDA's Agriculture and Micro-Finance Projects: 55-74. (A Report Submitted to Mennonite Economic Development Associates).

Hashemi, S. M., Schuler, S. R. \& Riley, A. P. (1996). Rural credit programs and women's empowerment in Bangladesh. World Development, 24 (2), 635-53.

Hossain, M. (1985). Rural Development Study (Volume 2). Bangladesh Institute of Development Studies, Dhaka.

Hossain, M. (1988). Credit alleviation of rural poverty: the Grameen Bank in Bangladesh. Research Report No. 65, International Food Policy Institute, Bangladesh.

Hossain, M. (1993). The Grameen Bank: its origin, organization and management style. In A.N.M Wahid (ed.) The Grameen Bank and Poverty Relief in Bangladesh, Westview Press, Boulder.

Hulmi, D. (1990). Can the Grameen Bank be Replicated? Recent experiments in Malaysia, Malawi and Sri Lanka. Development Policy Review, 8(3), 287-300.

Huppi, M. \& Feder, G. (1990). The role of groups and credit cooperatives in rural lending. The World Bank Research Observer, 5 (2), 187-204.

Jain, P. \& Moore, M. (2003). What makes microcredit programs effective? Fashionable fallacies and workable realities. IDS Working Paper 177. Brighton: Institute of Development Studies.

Jammeh, M. E. (2002). Access to Finance in the Artisanal Fisheries Sub-Sector of the Gambia. Presentation Made at the Workshop on Artisanal Fisheries and the World Markets (11-12 April 2002): Administration Of Agricultural Credit Schemes with Reference to the AFDP Credit Program.

Khandker, S. R., Khalily, B. \& Khan, Z. (1995). Grameen Bank: performance and sustainability. World Bank Discussion Papers No. 306, World Bank, Washington D.C.

McDonnell, S. (1999). The Grameen Bank Micro-credit Model: Lessons for Australian Indigenous Economic Policy. Discussion paper. Centre for Aboriginal Economic Policy Research no. 178. Canberra: Australian National University.

Mehta, Aasha K. \& Amita, S. (2003). Chronic Poverty in India: Incidence, Causes and Policies. World Development, 31(3), 491-511.

Morduch, J. (1997). Micro finance Sustainability: a consistent framework and new evidence on the Grameen Bank. Discussion Paper - draft, Cambridge: Harvard Institute for International Development (HIID).

Murthy, L. (2005). Banking on Poor Women. Available at http://infochangeindia.org/ 200510056113/Micro-credit/Backgrounder/Banking-on-poor-women-Grameen-Bank.html

Murthy, L. (2005). Women's empowerment, or a debt trap. Available at http://infochangeindia.org/200510036115/Micro-credit/Backgrounder/Women-s-empowerment-or-a-debt-trap.html

Rahman, A. \& Hasnat, B. (1993). Housing for the rural poor: the Grameen Bank experience. In A.N.M Wahid (ed.), The Grameen Bank Poverty Relief in Bangladesh, West view Press, Boulder.

Rahman, R. (1986). Impact of the Grameen Bank on the situation of poor rural women. Grameen Bank Evaluation Project Working Paper No 1, Bangladesh Institute of Development Studies, Dhaka.

Rao, J. M. (1980). Interest Rates in Backward Agriculture: Notes and Comments. Cambridge Journal of Economics, 4, 159-167.

Rutherford, S. (2000). The Poor and Their Money. New Delhi: Oxford University Press.

Sharma, S. (2005). Micro-credit Improve Cash Flow but Doesn't Create Wealth. Available at http://infochangeindia.org/200510026116/Micro-credit/Backgrounder/-Micro-credit-improves-cash-flow-but-doesn-t-cr eate-wealth.html

Stiglitz, J. E. (1990). Peer monitoring and credit markets. The World Bank Economic Review, 4 (3), 351-366.

Todd, H. (1996). Cloning Grameen Bank: Replicating a Poverty Reduction Model in India, Nepal and Vietnam. IT Publications, London. 
UNDP. (1995). Human Development Report 1995, New York: UN: 230.

Varian, H. R. (1990). Monitoring agents with other agents. Journal of Institutional and Theoretical Economics, 146 (1), 153-74.

Wahid, A. N. M. (1994). The Grameen Bank and poverty alleviation in Bangladesh: theory, evidence and limitations. The American Journal of Sociology, 53 (1), 1-15.

Yunus, M. (1997). Quoted from the speech of Professor Mohammad Yunus delivered at the Micro-credit Summit, February 2-4, 1997, Washington D.C.

Zaman, H. (2004). The Scaling-Up of Micro Finance in Bangladesh: Determinants, Impacts and Lessons. World Bank Policy Research Working Paper 3398, September, 2004.

Table 1. Top 10 Microcredit Summit-verified Bangladeshi MFIs, based on number of poorest clients

Source: Daley-Harris (2005)

\begin{tabular}{|c|c|c|c|c|c|}
\hline $\begin{array}{c}\text { Micro Finance } \\
\text { Institutions (MFIs) }\end{array}$ & $\begin{array}{c}\text { Number of } \\
\text { Poorest Clients }\end{array}$ & $\begin{array}{c}\text { Number of } \\
\text { Active Clients }\end{array}$ & $\begin{array}{l}\text { Proportion of Active } \\
\text { Clients who are poorest }\end{array}$ & $\begin{array}{c}\text { Number of poorest } \\
\text { who are women }\end{array}$ & $\begin{array}{c}\text { Proportion of poorest } \\
\text { who are women }\end{array}$ \\
\hline Grameen Bank & $4,060,000$ & $4,060,000$ & $100 \%$ & $3,897,600$ & $96 \%$ \\
\hline BRAC & $3,630,000$ & $3,990,000$ & $91 \%$ & $3,630,000$ & $100 \%$ \\
\hline $\begin{array}{l}\text { Bangladesh Rural } \\
\text { Development Board }\end{array}$ & $3,528,041$ & $3,713,728$ & $95 \%$ & $2,399,068$ & $68 \%$ \\
\hline ASA & $2,490,000$ & $2,770,000$ & $90 \%$ & $2,390,400$ & $96 \%$ \\
\hline Proshika & $1,236,104$ & $1,545,130$ & $80 \%$ & 803,468 & $65 \%$ \\
\hline Sonali Bank & 500,000 & $3,800,000$ & $13 \%$ & 365,000 & $73 \%$ \\
\hline Caritas & 251,273 & 284,947 & $88 \%$ & 173,378 & $69 \%$ \\
\hline $\begin{array}{l}\text { Thenamara Mohila } \\
\text { Sabuj Sangha }\end{array}$ & 250,664 & 278,516 & $90 \%$ & 238,131 & $95 \%$ \\
\hline BURO Tangail & 221,366 & 221,366 & $100 \%$ & 219,152 & $99 \%$ \\
\hline $\begin{array}{l}\text { Rangpur Dinajpur } \\
\text { Rural Service }\end{array}$ & 175,713 & 228,199 & $77 \%$ & 140,570 & $80 \%$ \\
\hline Total & $16,343,161$ & $20,891,886$ & $78 \%$ & $14,256,767$ & $87 \%$ \\
\hline
\end{tabular}

Table 2. Roles needed for turning commercialization a success

\begin{tabular}{|c|c|c|c|}
\hline Roles of Government & Roles of Funding Agencies & Roles of MFIs & $\begin{array}{l}\text { Roles of } M F \text { industry } \\
\text { support organizations }\end{array}$ \\
\hline $\begin{array}{l}\text { 1. Providing enabling policy environment } \\
\text { 2. Phase out direct interventions that distort } \\
\text { the market for microfinance } \\
\text { 3. Focus on grant based approaches to assist } \\
\text { the poorest } \\
\text { 4. Create a new legal structure for commercial } \\
\text { MFIs } \\
\text { 5. Adopt appropriate regulation and } \\
\text { supervision for microfinance } \\
\text { 6. Improve the framework for secured } \\
\text { transactions }\end{array}$ & $\begin{array}{l}\text { 1. Support an effective } \\
\text { policy, legal and regulatory } \\
\text { environment } \\
\text { 2. Build MFI institutional } \\
\text { capacity } \\
\text { 3. Support innovation in } \\
\text { enterprise development } \\
\text { 4. Promote linkage } \\
\text { development }\end{array}$ & $\begin{array}{l}\text { 1. Balance } \\
\text { commercial and } \\
\text { social objectives } \\
\text { 2. Increase cost } \\
\text { efficiency } \\
\text { 3. Improve } \\
\text { institutional capacity }\end{array}$ & $\begin{array}{l}\text { 1. Role of PKSF } \\
\text { 2. Role of CDF } \\
\text { 3. Role of Credit } \\
\text { Information Bureau } \\
\text { (CIB) }\end{array}$ \\
\hline
\end{tabular}

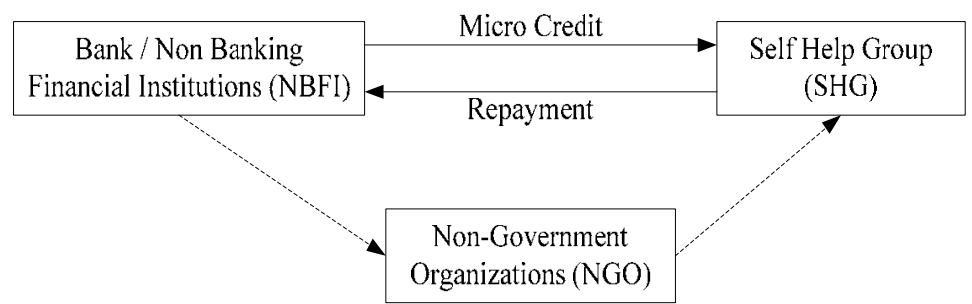

Figure 1. Traditional Micro Credit Model 


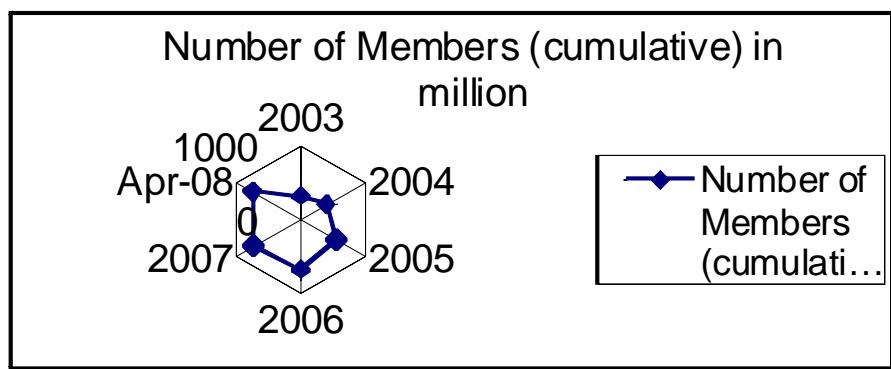

Figure 2. Increasing number of beneficiaries of micro credit

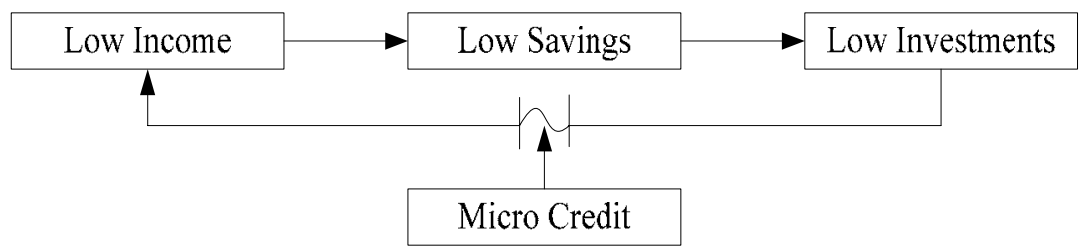

Figure 3. Breaking the Vicious Circle of Poverty: The Grameen Model

\begin{tabular}{|c|c|}
\hline \multirow{3}{*}{ 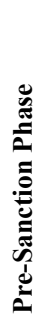 } & $\begin{array}{l}\text { Formation of a } 5 \text {-members group who are homogeneous in terms of age, sex, } \\
\text { location, knowledge and social status }\end{array}$ \\
\hline & $\begin{array}{l}\text { Participation in a weeklong training program to be familiar with the rules and } \\
\text { regulations }\end{array}$ \\
\hline & $\begin{array}{l}\text { Jump to next step if their performance is satisfactory. And if the performance is not } \\
\text { up to satisfaction, the process stops here. }\end{array}$ \\
\hline \multicolumn{2}{|r|}{ Loan is sanctioned and given to the group } \\
\hline \multirow{3}{*}{ 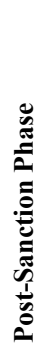 } & $\begin{array}{l}\text { Each member identifies the purpose of the loan consulting with the other members } \\
\text { of the group. }\end{array}$ \\
\hline & $\begin{array}{l}\text { For repayment, each and every member of the group is liable up to the total amount } \\
\text { of the loan. }\end{array}$ \\
\hline & $\begin{array}{l}\text { Mutual accountability establishes a form of social capital replacing financial capital } \\
\text { (commercial viewpoint) that ensures the timely recovery of the fund. }\end{array}$ \\
\hline
\end{tabular}

Figure 4. Grameen Model of Microcredit - at a glance 


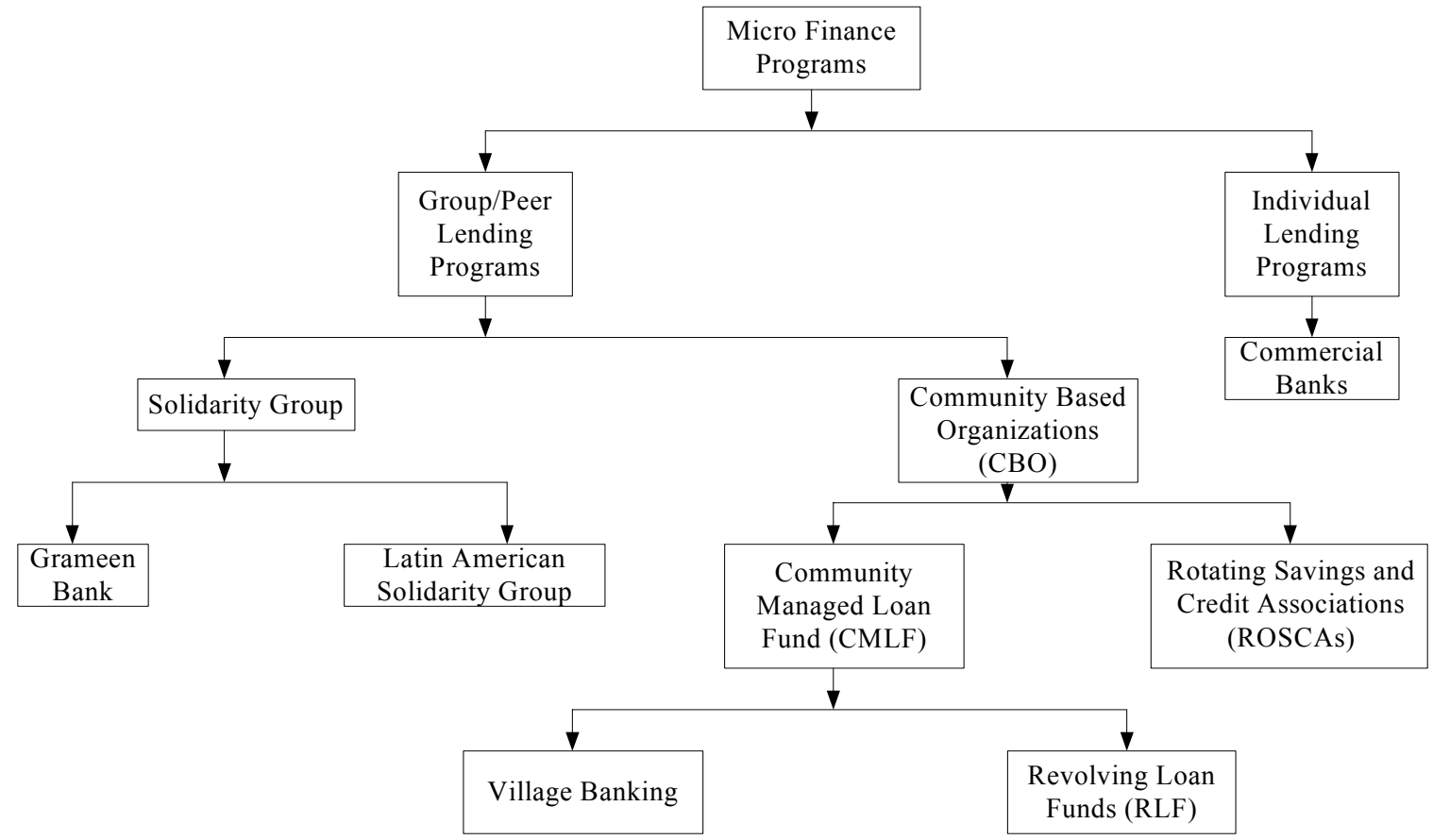

Figure 5. Different Types of Micro Finance Programs

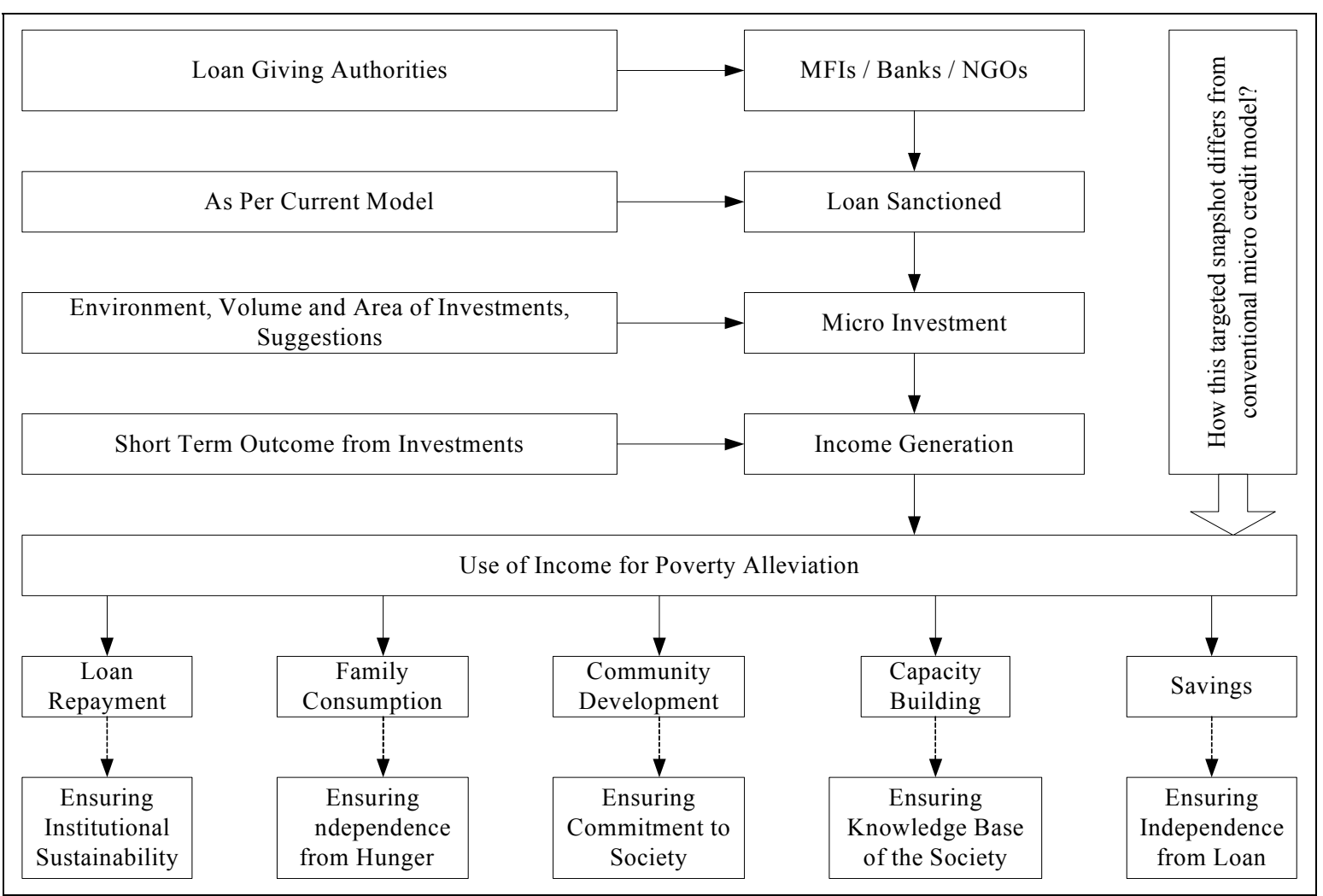

Figure 6. Micro Credit Model for Long-term Poverty Alleviation 


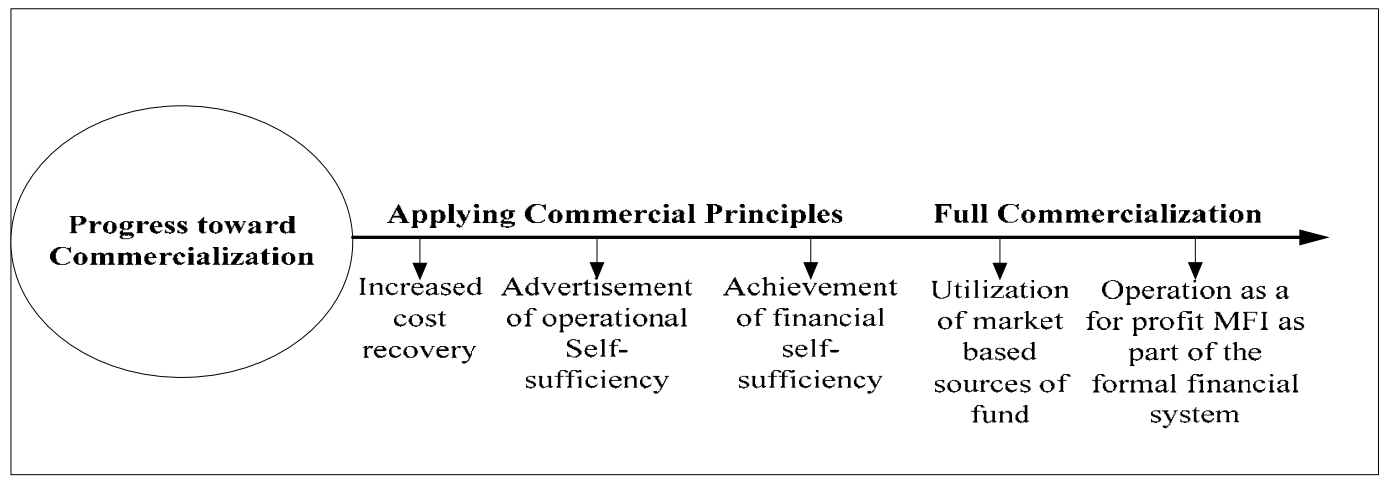

Figure 7. MFI Commercialization Continuum

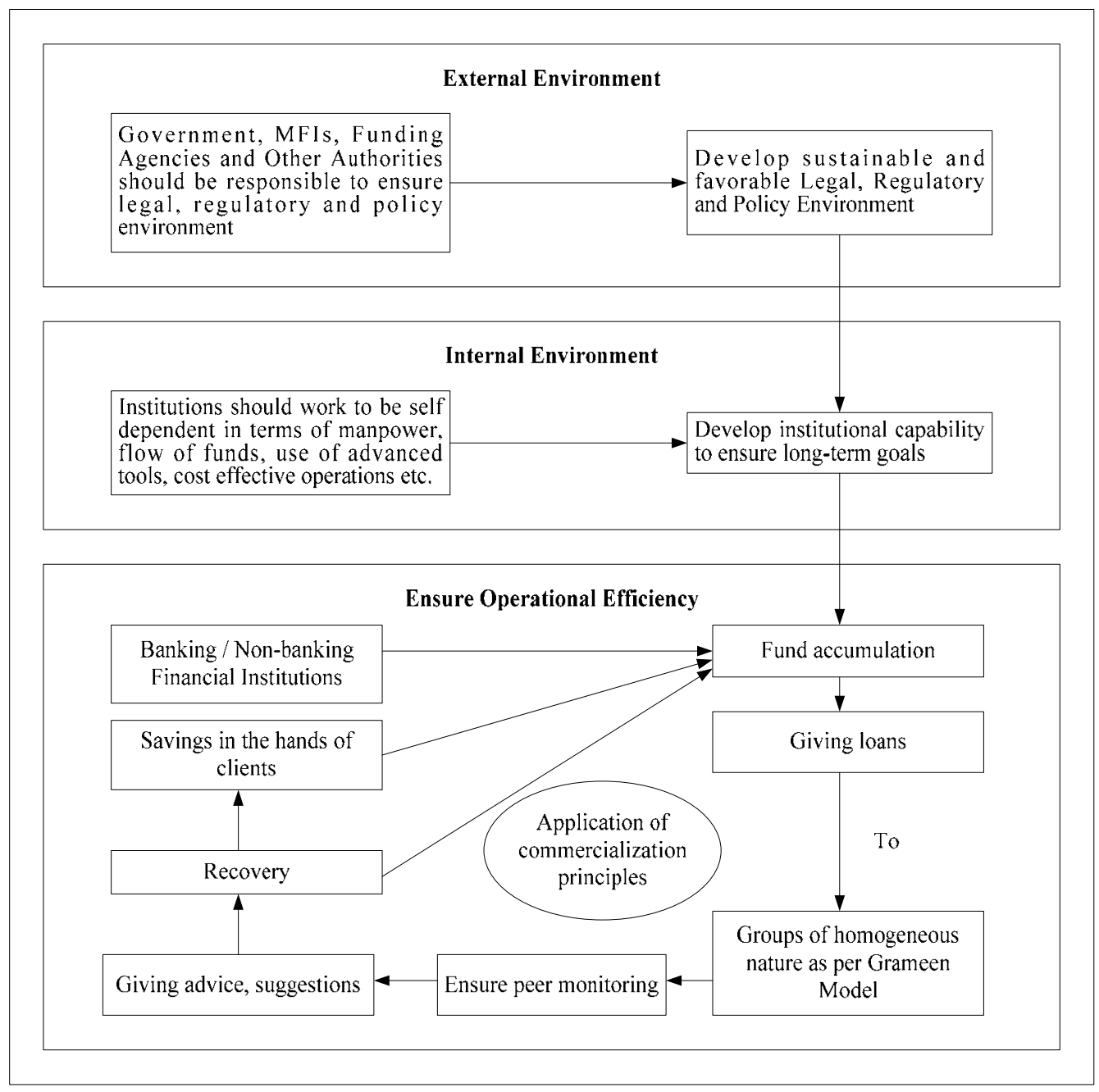

Figure 8. Microfinance Commercialization Model 